\title{
ASSESSMENT OF THE INTEGRATED SYSTEM ON THE EXAMPLE OF THE BALDINO ARTSTORE Sp. z o.o. COMPANY
}

\begin{abstract}
The present article consists in an assessment of the integrated management system on the example of Baldino Artstore Company which produces natural ice-cream. Baldino Artstore is a young company founded in 2015, located in Wroclaw in Krakowska Street. The company produces ice-cream and sherbets which are delivered to five shops in Wrocław and one in Nysa. The company employs 60 workers; during the summer season the number of employees doubles. Baldino is frequently referred to as "manufacture" because all goods they produce are hand-crafted, with the aid of modern and automatized devices. Baldino - cream and sherbets are made of natural ingredients and fresh products from a wide range of raw materials, from sweet to salty. The management system which operates in the company integrates various subsystems and facilitates an advanced management of quality, environment and work hygiene, fulfilling all requirements of food safety management for food producers, in accordance with the Regulation (EC) No 852/2004 of the European Parlament and of the Council of 29 April 2004 on the hygiene of foodstuffs. Each production stage is subject to internal control, beginning with the preparation of mixtures, pasteurization, filtering, maturing, freezing, up to the final stage of packaging. The norms functioning in the company include PN-EN ISO 9001 and PN-EN ISO 22000 (PN ISO 9000:2001. System Zarządzania Jakością - Podstawy i Terminologia; Wymagania) $(1,2)$ the means of a survey among the company's employees. The questions asked included: the employees' awareness of systems functioning in Baldino Artstore, depending on the position a particular employee holds in the company; the employees' opinion on the advantages of the integrated management system, as well as its drawbacks. The employees who too and categorised into following groups: up to 6 months, between 7 and 12 months, and over 12 months. The article presents a detailed discussion of the employees' answers and the implications of what the results reveal.
\end{abstract}

Keywords: Baldino Company, Integrated System, ISO 22000, sherbets

\section{Overall characteristics of the research subject - Baldino Artstore Company}

Baldino is a young company created in 2015. It is located in Wrocław on Krakowska Street. According to the Polish Classification of Products (PKD) Baldino belongs to section $\mathrm{C}$, i.e. the production of grocery articles, more specifically production of ice cream. This subclass encompasses the production of ice cream and other frozen desserts, for example sherbets. Baldino Company's articles are produced in accordance with the trade norm ISO 22000 (http://www.pkd.com.pl/ wyszukiwarka/pkd/). Initially the produced ice cream was delivered to two shops in Wrocław; now the company's activity has expanded and its products are delivered to

\footnotetext{
${ }^{1}$ Prof. nadzw., UE Wrocław, katarzyna.szoltysek@ue.wroc.p
} 
five shops in Wrocław and one in Nysa. The plant employs 60 workers, and in high season even up to twice more.

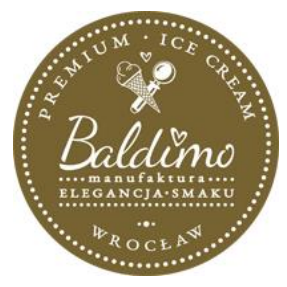

Fig. 1. The company logo.

Source: the author's own source

Baldino is often referred to as 'manufacture' because all its products are crafted by hand, with the aid of modern automatized equipment which greatly enhances and improves the production process.

The ice cream and sherbets by Baldino are made from natural ingredients and only fresh products. They are produced according to a traditional recipe, often enriched with mixture of many raw materials, from sweet to salty. No preservatives or chemical additives are used.

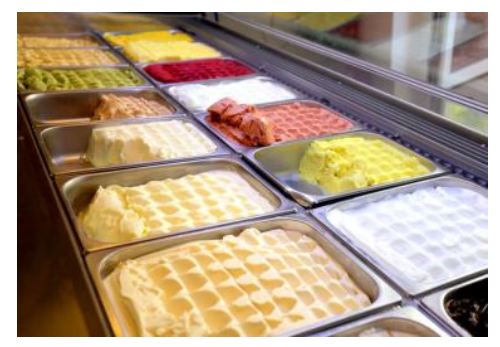

Fig. 2. A selection of Baldino ice cream.

Source: the author's own source

Baldino meets the requirements for food producers according to the Regulation no. 852/2004 of the European Parliament and Council of Europe. All stages of production are closely monitored, beginning with the preparation of the mixtures, pasteurization, filtering, maturation, freezing, up to packaging. The company employs the Integrated System working upon norms such as PN-EN ISO 9001 and PN-EN ISO 22000. The ISO 22000 standard means that the company fulfils the requirements of the HACCP System, which enables risk identification and their swift elimination. The ISO 22000 international norm sets out guidelines for the system of food safety such as 
risk analysis and critical control points HACCP. Within the norm, also the following requirements are met:

- Planning, implementation and application of the system of food safety management.

- System integration with other official and executive requirements of food safety.

- Definition of customer expectations and introduction of actions to increase their satisfaction.

- Communication between all components of the food chain.

- Ensuring other parties about the company's dedication to meeting all requirements.

- Certification.

- ISO 22000 sets out also a range of norms dealing with food.

- ISO 22000, Food Safety Management System: Requirements.

- ISO/TS 22003, Food Safety Management System: Requirements for auditioning and certifying units.

- ISO/TS 22004, Food Safety Managemet System: Guidelines.

- ISO 22005, Identifiability in the food chain: General Guidelines.

\subsection{Organizational structure}

Baldino Artstore Sp. Z o.o. is managed by a two-member board which is responsible for directing the company's actions and its representation. The following are directly subject to the board:

- Finance and Administration director in charge of the Human Resources and Accounting.

- Production director in charge of the vice-director for technical maintenance, vicedirector for production, vice-director for logistics, and quality expert.

Ever since its foundation, the company has based on a functional structure, which has proved very successful and efficient. Each department is managed by its dedicated director who directly answers before the board. The directors are equipped with concrete knowledge and expertise which allow them to succeed in their roles. Such an organisation facilitates communication between supervisors and employees, and makes it easier for employees of given departments to reach out to one another. Thus, a functional structure is very clear and duties division transparent.

\subsection{Product range and assortment}

Baldino offers natural ice cream, made from natural ingredients, crafted by hand with the aid of modern machines and devices which enhance the production process, which proves extremely useful especially in high season, when the plant distributes up 
to $750 \mathrm{~kg}$ of ice cream daily. The company has some fixed ice cream flavours, constantly available, as well as some seasonal sherbets from fresh fruit, available during the summer. The assortment is presented in Table 1 .

Table 1. Baldino ice cream assortment

\begin{tabular}{|c|c|}
\hline Fixed flavours & $\begin{array}{l}\text { - vanilla ice cream, } \\
\text { - chocolate ice cream, } \\
\text { - vanilla ice cream with dried fruit, } \\
\text { - pistachio ice cream, } \\
\text { - coffee ice-creams }\end{array}$ \\
\hline $\begin{array}{l}\text { Tastes of the } \\
\text { day / week }\end{array}$ & $\begin{array}{l}\text { - Ice cream with gorgonzola cheese and walnuts } \\
\text { - Salty caramel ice cream, } \\
\text { - Peanut butter ice cream, } \\
\text { - Chocolate ice cream with chilli, } \\
\text { - Marshmallow ice cream. }\end{array}$ \\
\hline Sherbets & $\begin{array}{l}\text { - strawberries, } \\
\text { - mango, } \\
\text { - raspberries, } \\
\text { - Watermelon, } \\
\text { - Cherry, } \\
\text { - Pear. } \\
\text { In addition, there are non-standard flavours such as lime sherbet with basil, apple } \\
\text { sherbet with vodka, raspberry sherbet with meringue, and others }\end{array}$ \\
\hline
\end{tabular}

Source: own study

\subsection{Applied assessment method}

In order to assess the functioning of the integrated system in the company, surveys were conducted among employees on different posts, both managerial and nonmanagerial. In total, thirty five employees were given the questionnaire which aimed to learn as much as possible about systems implemented in the company, assets of the integrated system, as well as the system's weaknesses. When an employee reported a faulty functioning of the system, additional question was asked about what could be done to correct the fault and improve the system. The criteria used to differentiate between employees were their position in the company and their seniority. No suggestions were made in the survey which could in any way influence the answers of the employees. The following questions were asked: 1 . What is your position in the company? 2. How long have you worked for the company? 3. What management systems have been implemented in the company? 4. What are the strengths and assets of the functioning of the integrated system in the company? 5. What are the weaknesses of the integrated system? 6. How could the system be improved and enhanced? 


\subsection{Results of the conducted surveys}

All answers were carefully analysed and the final results were presented on diagrams. The survey and interview with the employees investigated also their awareness about the systems functioning in the company, especially in relation to the given employee's position and seniority. Also the strengths and weaknesses were analysed and discussed with employees. All strengths were grouped into twelve categories: 1. Rise in company's competitiveness, 2. Increased efficiency of management, 3. Quality improvement of products, 4. Better work organization, 5. Improvement of customer relations, 6. Better cost efficiency, 7. Fewer faulty products, 8. Better documentation coherence, 9. Marked company progress, 10. Improved company reputation, 11. Development of new technologies, 12. Stronger activisation of the management.

\section{Conclusions}

In order to improve the functioning of companies, enhance their market position and customer interest, specific systems were being implemented which helped companies achieve its goals. Depending on the type of a given company's activity, different procedures and strategies apply. As a general rule, usually several systems are implemented. In order to increase their efficiency, all systems may be integrated into one coherent and multi-functioning management system.

The investigated company carried out a full integration, which is evident in the coherence of documentation for all implemented systems - the company makes use of the quality book which sets out a joint quality policy for the quality management system and food safety management system. The surveys conducted among employees clearly show that the integrated system possesses many strengths. All respondents noticed the marked improvement in product quality and fewer cases of faulty products.

The second analysed aspect was the employees' knowledge of systems functioning in the company. It transpired that employee awareness depends on the position and seniority of an employee. Employees on managerial positions and those with greater seniority possessed a much greater knowledge of quality management systems ISO 9001 and food safety management systems ISO 22000, including also HACCP, and the GMP and GHP codices. In order to ascertain a proper and most efficient functioning of the integrated system it is vital that all employees be made more aware and involved, not only senior managers. Thus, the company should aim to expand the employees' awareness through a constant and dedicated knowledge dissemination. 


\section{Bibliography}

1. Co to jest Kodeks Żywnościowy? W: https://www.ijhars.gov.pl/pliki/kodeks/codex.pdf.

2. ISO 22000:2005. Food safety management systems - Requirements for any organization in the food chain. Foreword. W: https://www.iso.org/ obp/ui/\#iso:std:iso:22000:ed-1:v1:en

3. ISO 22000:2005. Food safety management systems - Requirements for any organization in the food chain. Introduction. W: https://www.iso.org/obp/ui/\#iso:std:iso:22000:ed1:v1:en

4. ISO 22000. W: http://iso-22000.pl/index.html

5. Oficjalna strona ISO. W: http://www.iso.org/iso/about/about

6. Oficjalna strona ISO. W: http://www.iso.org/iso/home/about/the_iso_story.htm\#2

7. Oficjalna strona ISO. W: http://www.iso.org/iso/home/standards/managementstandards/iso_9000.htm

8. PN-EN ISO 9000:2001. Systemy zarzadzania jakościa - Podstawy i terminologia.

9. PN-EN ISO 9001:2000. Systemy zarzadzania jakościa. Wymagania.

10. Polska Klasyfikacja Działalności

$P K D$. $\mathrm{W}$ : http://www.pkd.com.pl/wyszukiwarka/pkd/10.52.Z.html

11. RosZAK M., Zarządzanie jakościa $w$ praktyce inżynierskiej. W: http://www.openaccesslibrary.com/vol31/1.pdf

12. Rogala P., Brzozowski T. 2013. Systemy zarzadzania jakościa i środowiskiem. Wydawnictwo Akademii Ekonomicznej we Wrocławiu, Wrocław.

13. Rozporządzenie Rady Ministrów z dnia 24.12.2007 r. w sprawie Polskiej Klasyfikacji Działalności (PKD).

14. Rozporządzenie (WE) nr 178/2002 Parlamentu Europejskiego i Rady z dnia 28 stycznia 2002 roku.

15. Ustawa z dnia 25 sierpnia 2006 r. o bezpieczeństwie żywności i żywienia, Dz.U. z 2006 r., nr 171 , poz. 1225 , z późn. zm.

16. Zintegrowane zarządzanie jakościa. Wydawnictwo Uniwersytetu Łódzkiego, Łódź 2007. 